Original scientific article

UDC: 613.94(091)(485)

COBISS.SR-ID 219479564

Terry-Lee Marie Marttinen

Department of History

University of Saskatchewan

9 Campus Drive, Saskatoon, SK S7N 5A5, Canada

E-mail: terrymarttinen@gmail.com

\title{
SCANDINAVIAN ANTHROPOLOGY, EUGENICS, AND THE POST-COLONIAL GENETICIZATION OF SAMI CULTURE*
}

\begin{abstract}
Multidisciplinary Swedish/Sami religious reformer Lars Levi Laestadius, played a defining role in the medicalization of Sami and Swedish national identity in the development of colonial science in Scandinavia. Promoting a gendered concept of 'nervousness' inherent in Sami blood, a succession of eugenicists then popularized psychiatric theories of Sami inferiority late into the twentieth century. The ideologies emerged after a group of Sami Laestadians in Kautokeino, Norway murdered representatives of the government in 1852 in a revolt against trade practices and restrictions on reindeer herding. The hereditarian view of Sami mentality associated with female sexuality eventually led to the sterilization of Sami women and expanded medical research on Sami people. In transnational colonial experience, a cultural crisis was created among the Sami diaspora in North America. Emigrating to the United States and Canada in a mass migration between 1860 and 1920 to escape poverty, racism, and practice Laestadianism freely, Sami descendants are now reclaiming their indigenous identity. However, bio-identification through mtDNA as marketed by the current commercial genomics industry to those Sami assimilated into Scandinavian immigrant communities in North America may re-stigmatize the Sami as a collective. This article examines historical continuity between Swedish colonial medicine and contemporary eugenics impacting the Sami and argues a new cross-cultural scientific approach to major psychoses is required in psychiatry.
\end{abstract}

Key Words: eugenics, Sami, medicalization, psychosis, social stigma NonMeSH: indigenous populations, post-colonial genomics

\footnotetext{
* Research and editorial support for this article was provided by Dr. Marius Turda, Director of the Centre for Medical Humanities, Oxford Brookes University, Oxford, UK. Ellen Marie Jensen, PhD research fellow in Sami and Indigenous Research at The Arctic University of Norway assisted with edits related to Sami history. It is based on Master's dissertation work supervised by Dr. Turda in 2013-2014 with scientific support provided Dr. Hervé Perron, Chief Scientific Officer of GeNeuro SA in Geneva, CH.
} 
"There appears in certain Lapps a strange weakness of the nerves, or whatever one wishes to call this odd inclination of theirs: for some insignificant cause they lapse into a state of over-stimulation. This lends credibility to what older writers say about their noaides, namely that after special strain on the body and soul they sink into a kind of trance or magnetic sleep, during which the soul is in a state of rapture..." [1 p 207]

Nineteenth century botanist, ethnographer, psychologist, and religious reformer Lars Levi Laestadius was a state educated anti-materialist, who defended his pastoral thesis Crapula Mundi at Uppsala University in 1843. His father was Swedish and mother Sami, is best known for leading a pietistic revival within mainstream Lutheranism in northern Sweden that spread to Norway and Finland along Sami reindeer migration routes. This enigmatic figure has been mythologized as prophet and blamed for destroying Sami cultural beliefs, while several Sami and non-Sami researchers maintain that through his doctrine shamanism survived state ecclesiastical administration by integrating ancient symbols and allegories. Currently, Sami scholars [2] agree that while the missionizing period of Laestadius preserved elements of Sami tradition and language his movement that originally spread in Sapmi (formerly known as Lapland) represented a major shift in culture and social relations between Sami and other Nordic peoples. One of them, Anna Lydia Svalastog [3 p2] argues, for instance, that pre-Christian religion evolved variably among the Sami and that shamanism became an "individual encounter".

According to Sami feminists, Laestadianism played a definitive role in gaining national sovereignty over some Sami regions and in perpetuating the oppression of women. In a seminal book on minority/majority relations it was argued that religion conceptualized Sami women as sinners and males as alcoholics, which fit into Christian binary categories of culture/nature, mind/body, and man/woman that were incompatible with Sami philosophy.[4] In support of the counter-culture thesis, Gunlög Fur [5] demonstrated in Colonialism in the Margins: Cultural Encounters in New Sweden and Lapland that the Swedish crown regulated the public and private lives of Sami as early as the seventeenth century by instituting churches and courts in northern marketplaces. She suggested that Sami female and male sexuality was brought in line with Swedish national norms through the codification of beliefs and regulative measures associated with judicial and ecclesiastical processes. Confessional education and language was strategically utilized in Sweden and Norway to domesticate the Sami, evidenced by the establishment of nomad schools and religious instruction in Sami languages.

Rauna Kuokkanen [6] similarly argued that colonialism bound Sami women to a foreign identity and that a new model of autonomy is needed to promote female leadership today. Along with highlighting a lack of postcolonial analysis on colonialism in Sapmi, a subsistence economy is deemed necessary to overcome inequality normalized in Sami communities where multiple influences transformed gender and economic relations. This can be seen occurring over centuries of cultural regulation including educating male Sami clergy, as a part of nation-building that isolated women into the private sphere of their homes or forced them into public 
employment. Authoritarian rule over women's spirituality and bodies, as will become evident, was a precursor to the medicalization, sterilization, and assimilation of Sami people into mainstream northern European society.

Laestadius, influenced by the democratization of Lutheranism that began in the eighteenth century, transferred confessional power to the Sami community in a process of social change to pragmatic Christianity, but maintained paternal structures and earlier scholastic tendencies by producing prolific theological writings. There is growing body of research on Laestadius' intersecting roles as a botanist, cleric, and ethnographer; however, little is known about his nationalizing efforts as a psychological anthropologist and eugenicist prior to the rise of race biology in Sweden. This article examines Laestadius, using his recently discovered ethnography on the Sami and an autobiography written after a Norwegian Sami rebellion against trade related practices in 1852. Other texts and secondary sources such as those provided by Astri Andresen, Vuokko Hirvonen, and Petteri Pitikainen help to identify Laestadius as a modernist who endorsed a gendered assimilation of Sami people. As a pastor and director of Sami parishes, Laestadius studied the psychic life of Sami women and applied nineteenth century French psychological theory to explain religious ecstasy and alcoholism considered serious social problems in Sami communities.

As the spiritual leader of both Sami and Nordic people living in northernmost Fennoscandia, Laestadius is believed to have preserved Sami traditions in his teachings. Yet he can be seen as someone who also medicalized women as neurotic in step with contemporary psychiatrists, who pathologized mystical experiences common in nineteenth century revival awakenings spreading in protestant counties with the advent of pietism. I suggest that Laestadius introduced an interpretation of Sami women as heritably susceptible to nervous disorders in a multi world-view knowledge system. Fluid boundaries between Christian and scientific eugenic theories endorse Marius Turda's [7] assertion that eugenics often reveals a scientific pathos that has its roots in organised religion. Moreover, that the use of race and racial classification constitutes one of the central principles associated with eugenics. [8]

Colonial race psychological and physiological theories, I further argue, were initiated by a controversial rebellion in the mid-nineteenth century which centered on the mentality of the Sami. The event led to 'contagious diagnosis' that medicalized Sami socio-political problems and was the subject of three films in Scandinavia, one of which a Sami woman testified to being sterilized. [9] Links between the Sami uprising, economics, female sterilization, and social stigma will be drawn as well as parallels to the modern-day geneticization of Sami descendants in North America. It will be established the North American diaspora may be inadvertently restigmatizing Sami and Laestadians through questionable medical research practices marketed by commercial genomic firms. Furthermore, direct-to-consumer genetics infringes on the health rights of indigenous people-and transition to a postgenomic understanding of psychosis is required.

My aim in this article therefore is to draw attention to the transhistorical and transnational pathologization and invizibilization of Sami women that has led to an 
identity crisis among Sami descendants in North America. This entails looking at how identity is socially structured to reveal continuity and discontinuity between Old and New World Sami experiences linked to colonial eugenics.

\section{Background}

Colonial eugenics, as concept and practice, denotes religious, political, scientific, and/or medical interventions in human cognition and reproduction based on gendered theories of biological race that promote the assimilation or genocide of indigenous people. Positive forms endorse interference in sexual unions and marriage among indigenous and non-indigenous individuals and include forced legal identity to advance assimilation. Negative modes involve extermination of the indigenous through systemic marginalization of women and men by means of racebased laws and policies that promote:1) maternal and infant morbidity and mortality and; 2) economic, social, political, geographical isolation or institutionalization that foster social fragmentation, disempowerment, and child/ adolescent/adult morbidity and mortality.

Intergenerational psychological and physical traumas are internal to colonial eugenic dynamics, which became stabile over time and space with the inscription of racialized concepts of indigeneity in law, census, and government policy as well as scientific and medical research and their applications. Dirk Moses [10] points out that the century between 1850 and 1950 marked a period of intense ethnification of populations that culminated in the Holocaust and other genocides in Europeand took on distinct national features in history. Furthermore, certain patterns of extinction among the indigenous populations reveal that cultural genocide is not isolated from biological genocide, as portrayed by neo-liberal theorists.

In the colonization of Sami people in Scandinavia, eighteenth century philosopher Immanuel Kant [11] played an important role. He described Norwegian Sea Sami as under-developed. During the same period, the Sami people were compared to American Indians and believed by the Governor of Finland Per Brahe as well as Swedish upper classes to be savages in need of moral guidance and education to ensure their social progress. They were placed at the lowest level of a racial hierarchy, since their bodies considered exotic and behaviour offensive to God created in the image of Europeans presumably warranted it. [5] By 1922, the Swedish Institute for Race Biology was established in Uppsala where Laestadius proclaimed in the defence of his doctoral thesis "a Lapp is a man of better quality than a new settler or Non-Lapp". [1 p27] In the transition from colonial to mainline eugenics, the Sami were normalized as the standard of Nordic inferiority by Herman Lundborg and Norwegian eugenicists.

Laestadius, an ally of the Sami as indicated by his twelfth thesis, paradoxically conceived of a gendered construction of race in his psychological anthropology, which was then integrated into twentieth century secular eugenics. He wrote the three volume treatise Darhushjonet (or the Madhouse Inmate), before 1851. In Carl Hallensreutz's [12] 2014 review and a translation of writing on chief passions, [13] 
Laestadius was noticeably influenced by classical theories of emotions. In considering atonement as a mental act, females were iconicized through the dichotomous struggle between love and self-righteousness in an allegory of a mother's love that had to be denied to transcend passion, or sin. With the organic hypothesis relying on inverse imagery of Christian blood sacrifice, passions imagined as personal devils-the worst of which was egoism coupled with female sexuality and selfknowledge-transformed the female blood and ultimately caused disease. Power and freedom associated with the democratic nation was symbolized as a devil in the ego associated with female passions, and collectively stigmatized women by portraying Sweden as a harlot in a literal interpretation of Christian text.

Although Roger Kvist [14] suggested that Sami and Swedish drinking behaviour was comparable, Sami men were presumed to be inborn alcoholics and their intelligence blunted under the influence of alcohol by means of seven individually distributed passions that mingled with their blood and stimulated the nervous system. By applying the liberal economic theory and principles of the passions popularized by French physician Jean-Baptiste Descuret (1795-1871) ${ }^{1}$ it was assumed that blood altered by alcohol would turn black and cause anxiety. This was in agreement with his 1843 dissertation that addressed the decline of theocracy, in which Laestadius diagnosed Sweden and rest of the world as having degenerated to self-violence and insanity in the pursuit of democratic freedom. [15]

Notably, in Thomas Hobbes's (1588-1679) [16] political psychology that defended the monarchy causal interaction between desire (good) and aversion (evil) was assumed to produce motion and sensory experience necessary for cognitive development. Unlike John Locke (1632-1704) who later described mental disorders as determined undeveloped thought weak and strong passion ascribed to a person's constitution resulted in 'stupidity' and 'madness', which justified centralized corporal power and authority. For Hobbes, sovereignty was self-perpetuating and minds incapable of acknowledging their obligation to a sovereign power had no choice but to accept the morality of the market. In the materialist philosophy, a monarch depicted as a beneficent monster rather than religion prevented social degeneration and anarchy. [17]

In Laestadius's ethnography on the Sami, written between 1838 and 1845 and commissioned by the French Admiralty in a research expedition to Karesuando where he was pastor until 1843, a gendered race-based understanding of Sami personality informed by Enlightenment values was offered, which also appears in writing on Sami deities and noadi. In field notes first published in Swedish in 1997, uneducated women as well 'brutes' and 'savages' were described as suffering from weak nerves that forced mental power outward to external objects. [1 p63] The intellectual's ideology that held marginalized socially and racialized classes lacked

1 Jean-Baptiste Descuret practiced medicine in Paris and was awarded a medal of honour in 1845 for his work with victims of cholera. He conducted class-based studies on human emotions to inform his theory of the passions, which Laestadius applied to Sami cognition after he participated in the French Recherche expedition between 1838 and1840. The expedition was intended to answer social questions related to human 'race', language, and history. For further details see the introduction of Fragments of a Lappish Mythology. 
rationality, locates Laestadius as a transitory modern psychologist contributing to settlement of the Sami in Sweden. In the country, pastors were traditionally also mental health physicians, [18] and his cultivated views on nervousness associated with moral degeneracy endorsed Laestadianism as an alternative culture.

\section{Gendered Race and Medicine}

Andreas Heinz [19] has argued that during the nineteenth century, industrialization with its rising affluence and middle-class introduced new anthropological approaches to the understanding of behaviour and diseases as physical manifestations. Rather than an absence of reason advanced by early liberal philosophers, unfamiliar or socially disruptive conduct began to be related with poor mental functioning and immorality. In a series of intersecting changes that occurred in the shift to modernity, anthropology sought to understand physical, intellectual, and moral dimensions of man. This led to an increasing focus on comprehending the role of social contagion in disease-and the rise of psychiatry as a discipline. Enduring perceptions of a physical relation between passions and 'primitive' races together with social turmoil caused by the separation of church and state, influenced Laestadius's discussion of mental degeneracy. In La Medicine Passions (1841), the French physician Decuret insisted that the passions are instinctive and immorality was the cause of deteriorating intellect and reason. Such a view became a medical reference for students and the first psychiatrists in Spain, during the mid-nineteenth century. [20] Laestadius references Decuret in his autobiography and psychological discourses and applies his knowledge on cholera rooted in Miasma theory to the mind.

In his cultural anthropology as a forerunner to therapeutic applications Laestadius held that the souls of Sami were capable of being freed from the body, while older women succumbed easily to a state of over-stimulation. In his religioscientific framework weakness of the nerves was indeterminately attributed to possible isolation, food choices, and inheritance. Compatible with enduring descriptions of females stereotyped as sinners (or more violently whores) outlined in Sami feminist discourses, women were believed by eighteenth century ethnographer Johannes Tornaeus who is cited in Fragments of a Lappish Mythology to possess a "wild nature". In Sami the term' keuvot' means to "act like a lunatic", which some women otherwise associated with childhood trauma and fears. [1 p207-208]

\section{Religious Symbols and Nationalism}

In Leastadius's sociological construction of identity female symbols were persuasively used to appeal to Sami, while upholding ideals of a patriarchal racialized nation. Building on Lutheran orthodoxy to model the mundane world as degenerate, he advanced a dualistic imagery captured in Darhushjonet and personified by the Sami woman Milla Clemensdotter, who in Catholic tradition came to be known as Mary of Lapland. Clemensdotter, a parishioner from the Readers movement inspired 
intense feelings that led to the conversion of Laestadius to ascetic beliefs in 1844, during a chance encounter. His masculine experience of spiritual renewal mediated through the self-effacing Reader woman recited in his autobiography The Voice of One Crying in the Wilderness became the archetype for male transcendence, which assisted in the spread of Laestadianism. The Christian objectification of Sami females stood in contrast to pre-Christian goddesses in Sami mythology who authoritatively crafted temporal bodies and assisted in the birth of humanity. [1]

Religious signs of misogyny served to legitimize historical structures that idealized women based on colonial principles of subjugation and marginalized females. Symbols and practices associated with Swedish nationalism co-existed within the scope of normative race, family, gender and sexual relations, and developed in local contexts. In the early 1900's Laestadius's model of lay religious power co-represented by a Cartesian understanding of feminine identity acted as a hegemonizing influence, which controlled women through education and reproduction in Sweden. This joined state and Sami territory, reflecting Roger Friedland's [21] argument that national religion functions to masculinize culture, but the process was not linear. Resisting pronatalist ideology Swedish-Sami writer Sara Ranta-Rönnlund (1903-1979) overtly criticized Laestadianism indicating women were considered "prone to choose the path of sin" and suffered and died from the morality of preachers, including in childbirth. [23 p180-181] Sami men were typified as spiritual leaders, and conversely, drunkards ruled by passions 'mixed with the blood. Temperance laws applied to the Sami predated mainline eugenic beliefs that alcohol had a destructive influence on heredity material and contributed to the decline of Norwegian society. [22]

\section{Sami Colonization and Uprising}

Pre-Christian, Christian, and secular knowledge evolved to produce an inferior racialized pubic image of the Sami. This was assisted by a separate school system that reindeer herding Sami children from Sweden attended. During the nineteenth century, policies of assimilation and segregation directing Christian schools kept nomad Sami from intermixing with settled Sami and Swedes to aid in controlling their official status as cultural bearers of Sami identity. [24] The ruling which was in place from 1827 onwards denied Sami in Norbotten the right to inherit land, as a precursor to the limited government protection in 1870 of reindeer herders. [25] With the passing of 1886 and 1898 reindeer grazing acts, Sami ethnicity was defined by occupation and legally instituted. Endorsing economic classification of the Sami as 'male primitive hunters', Laestadius was instrumental in establishing mission schools in Pajala with his partner Juhani Raattamaa where he was director of parishes after 1849 , until his death in 1861 . The schools evaded a ban on non-Lutheran liturgy and were used to teach Christianity to reindeer Sami alongside the curriculumand became a template for Laestadian churches. Internally colonizing Sami using methods of confessionalization, several teachers from the mission schools became preachers and spread Laestadius's beliefs to Norway and Finland, which split after Raattamaa died. 
Renowned for doomsday sermons rooted in the Reader and Shouter movements that narrowly controlled Sami women where asceticism was embraced, [23] Laestadius's teachings strained relations between Sami people and Swedish, Norwegian, and Finnish settlers. Known to arouse a state of extreme ecstasy in parishioners, complaints were made to the governor and bishop's council and a separate church had to be built for Laestadians in 1853 in Pajala. This occurred after scrutiny of the faith by state authorities when a group of thirty-five Sami attacked a non-Sami merchant, sheriff, priest and his family on 8 November 1852 in Kautokeino, Norway. Led by Mons Somby and Alask Haetta who were trained by Laestadius, the sheriff and merchant were murdered and the pastor was severely beaten. After the trial that followed, Somby and Haetta were executed and other participants were imprisoned. Laestadius was questioned for inciting fanaticism in his followers, but was absolved of liability stating in his defence that he was not responsible for individuals distorting his doctrine or their violent behaviour. [2]

Economic factors implicated in the uprising, included restrictions on reindeer herding due to border closings between Norway and Finland that cut-off access to grazing lands. Trade was also a highly contested issue in the move from a hunting and fishing to an agricultural economy, which prompted Sami to migrate to Swedish and Norwegian coastlands in the mid-nineteenth century. [26] In Finnmark, alcohol was produced by Norwegian settlers in addition to farming in geography that was deemed too formidable to generate secure income, as a local development of nationalization in the north. Sale by colonial traders in Sami siidas (or family networks) and markets that were social hubs like in Sweden it is claimed was profitable, even though abstinence was practiced by Laestadians. [27] It is thought that the uprising was ignited in part by the sale of alcohol to Sami living in widespread poverty.

Laestadius himself was poor with a large family--and in bad health. Selfdescribing hallucinations in childhood and seeing a fire in the sky over the Karesuando church in 1847, [28] it was later commonly thought that he was 'insane'. It remains an open question whether his experiences of psychosis were related to a medical condition and if they influenced his religious psychology and ministry. We can however surmise that Laestadius's moral attitudes along with his followers Somby and Haetta played some part in Sami conflict with authorities, together with doctrinal disputes and other provocations.

\section{The Medicalization of Sami People}

Generally, nuanced ways that gendered race meted out in colonization of the Sami and the relationship to twentieth century eugenics is neglected in literature. Although addressing their intersection and the relationship between the Sami movement and colonial medicine in Norway with the 1999 film Give Us Our Skeletons, Paul-Anders Simma connected the Kautokeino insurgency to descendant Niillas Somby involved in protest over a proposed Norwegian hydroelectric power plant in 1980-1981. Somby lobbied the government to return the skull of his relative 
that was confiscated for burial in an expose on race biological research on the Sami. He drew attention to the legacy of abuses and protest in Finnmark, including violence against women who experienced shock treatment and sterilization in psychiatry. In documents of court proceedings in the trial of Somby's relative and other Sami, racial prejudice was an obvious factor based on a description of Sami as savages trying to break from natural barriers between themselves and superior Nordic society. [29]

Medically supporting inferiorization of Norwegian Sami, Laestadius [30] argued in his autobiography that, after the Kautokeino tragedy, a healthy mind accompanying intelligence facilitated knowledge of the passions, or sin. In a gendered hierarchy of passions, base passions were stated to cause blood to blacken and clog the heart chamber and produce hysteria in women. With the model of society projected onto the mind, excessively stimulated emotions reported among Sami Laestadians led to sickness and death. Unlike his anthropology where environmental causes were attributed to nervous disorders, a servant girl ${ }^{\star}$ was said to have 'phlegmatic temperament' and a 'reticent character'. According to Laestadius's updated theory of cognition mediated by the senses she was naturally predisposed to illness, therefore, upon hearing a sermon became ecstatic. In accounts of visons and ecstasy in mainly women diagnostically associated with melancholy Laestadius recorded he inherited from his mother, an altered emotional state led to salvation by forming concrete images of emotions in subjective consciousness. In the evolving knowledge structure base passions associated with sexual promiscuity in females and alcoholism in males was believed to cause poverty-which was technically updated by twentieth century eugenicists. $^{2}$

Consistent with interpretations affirming ancient beliefs that women are hysterical, Laestadius pathologized Sami women. Later, with the popularization of neurosis in 1880 that coincided with the rise of bacteriology, [18] a racist research paradigm of Sami psychopathology emerged out of colonial medicine. By 1922 Johan Rosberg published Lapp Psyche in a wave of eugenic theories on the Sami mentality, advancing that nervousness was a dominant racial trait. Responding to rising fears of racial intermixing, he argued blood mixing or interbreeding between Sami and Finns in Norway caused individuals to become phlegmatic. [31] At the same time, Jon Alfred Möjen [32] advanced that racial blood-crossing caused mentally disturbed race elements. This was consistent with his theory that endorsed alcohol deteriorated hereditary material. In Sweden with the growth of eugenics as a scientific discipline, Herman Lundborg established The State Institute for Racial Biology in 1922, devoting much of his efforts to corresponding studies on the physical attributes of the Sami. Like Laestadius, Lundborg applied apocalyptic parables of death and renewal in an attempt to prove that Sami communities were a homogenous race and a threat to the host nation. As Marius Turda explains, [7] Lundborg focused on the protection of the individual and race to defend the nation from degeneration, which was the standardized view among Nordic eugenicists.

\footnotetext{
* In Voices from Sapmi on p. 182 it is outlined that Swedish Sami female servants in the early 1900's were considered the lowest level in a social hierarchy and often became sick from overwork. This suggests that Laestadius conducted a gendered class study of ecstasy and psychopathologized Sami social problems.
} 
With an increasingly nationalized cognitive map projected onto human consciousness, in a post-colonial development an unknown number of Sami women were sterilized within a group 63,000 individuals in Sweden where over 90 per cent were females deemed mentally ill, feebleminded, physically deformed or weak and sexually deviant, until the 1970 's. As early as 1915, Nils Von Hofsten recommended social reforms to segregate cognitively impaired individuals such as the Sami and Finns studied in genealogical psychiatric research using surgical techniques. [22] The Sami are not overtly present among those sterilized with the passing of sterilization laws in 1934 and 1941, since ethnicity was not recorded in the surviving patient files. Yet, they are discernable as a group due to their intergenerational national identification as morally, emotionally, and intellectually inferior across Scandinavia.

\section{The Geneticization of International Sami}

The modern manufacture of hegemonic indigenous identity is a topic of ongoing debate and research by Sami scholars. New genealogical studies reveal that the Sami were invisibilized, along with their planned physical devastation through surgical intervention in Sweden. Not only did non-reindeer Sami lose official status with reindeer grazing policy, but the Name Act of 1901 forced many Sami to change their surnames to Swedish ones. Furthermore, women and children took on the nationality of husbands in census-while women who married Sami and their children's indigenous identity was calculated using eugenic blood fractions to support multi-level racial classification. As a result of de-ethnification the official number of Sami has been reduced to 20,000 reindeer owners, but there may be three times as many Sami in the country. [33,34] Similar dynamics in census taking existed in Finnmark, which cultivated paternalistic racial identities. This raises the question: how many Sami females were affected by Nordic sterilization policies? In Norway over 40,000 procedures were performed asymmetrically on women, like Sweden.

Anna Lydia Svalastog [35] in Making it Transparent. On Naming, Framing and Administering Biobank Research on Native People uncovered a hidden biobank containing Sami DNA in studies on polymorphic diseases that violate participant privacy and consent to research on a group level, as an emerging issue. She indicates that researchers continue to reductively biologize Sami identity, and in doing so, shape social discourses on what it means to be Sami in Sweden. A re-inscription of national categories of race can be seen, for instance, in an European Union gene-environment study involving several countries that absorbed research by Ulf Gyllensten conducted in 2000 that collected Sami blood samples from Karesuando and surrounding area.

The population of largely Sami where Laestadianism originated were assumed to be homogenous due to their social isolation and stability. Northern Sami communal identity ended up being traceable, since occupation and geographical data was disclosed in coding samples. The collections used for multifactorial disease research along with samples that were not destroyed in Gyllensten's project according to a research agreement discloses scientists failed to recognize they possessed Sami 
biobank specimens. This highlights the nuanced ways Sami identities are constituted and exploited, and the need for acknowledgement of traditional stewardship and rights of Indigenous people to control their own knowledge.

\section{North American Sami Codification}

In transnational Sami experience, in separate migrations in 1894 and 1898 Sami men and their families were recruited from Kautokeino to teach reindeer herding to the Inuit in Alaska to recover from exploited food resources from commercial overhunting. A group of men were later recruited to work in the Mackenzie Delta in Canada. While their cultural identity remained intact, a mass migration of northern Scandinavians that included Sami from Sweden, Norway, and Finland to North America between 1860 and 1920 to escape poverty, racism, and freely practice Laestadianism, generated an identity crisis among the Sami diaspora. North American Sami researcher Ellen Marie Jensen [36] indicates that 30, 000 to 60,000 thousand individuals with Sami ancestry are living in the United States and Canada wherever Scandinavians settled. Like in the Old World, memory of traditional identity was obscured by status criteria along with immigration processes, assimilation into new communities, and denial of identity by families impacted by racism in Scandinavia. With reculturation and revitalization movements that began in the 1980's, some Sami who cohabitated with Finnish and national immigrants in northern Sweden and Norway have reclaimed their lost identity. It is thought that up to 10 percent of Sami descendants in North America are aware of their heritage to some degree.

Personal genetic research was criticised in the media by the President of Norwegian Sami Parliament based on the fact that DNA testing is marketed to uncover lost Sami history in North American Scandinavian communities on the internet and Nordic festivals. Creating new biopolitical entities rooted in beliefs the Sami are genetically homogenous, direct-to-consumer companies are able to use biodata collected from females who test positive for modern Sami mtDNA U5b1 in studies that require large amounts of genetic information. On-line DNA databases promote consumer sharing with the appeal of locating statistical relatives that, in turn, increase the sales of tests to occupy on-line bionetworking communities. This functions to isolate DNA and creates unregulated Sami biobanks, analogous to the research projects in Sweden. In post-colonial genomics, Family Tree DNA and $23 \& \mathrm{Me}$ as industry leaders associated with the Genographic Project and Google sell, collaborate with pharma, or themselves use mtDNA for migration, disease risk, and ethnic drug research with the consent of consumers. In micro-racialized categories at the individual level, the Sami are fossilized as a primitive race frozen in time by ignoring cultural, social, and political dimensions of human identity and health. In a growing trend, $23 \& \mathrm{Me}$ markets health lifestyle information to circumvent a ban by the FTDA on the sale of genetic risk testing that aids in the expansion of pharmacogenomics research, which is left to buyers to apply to prevent disease. [37] 


\section{Post-colonial Eugenics and Stigma}

Comparable to Swedish and Norwegian Sami census, North American Sami female identity is quantified using population methods where socio-cultural meaning is negated. Lost in Sami matrilineal (and patrilineal through Y-DNA) genetic studies are legal identity questions and ethical issues related to international human rights and conventions intended to equalize health disparity, not to mention the legitimacy of genomics as a therapeutic tool. Researchers are able to circumvent indigenous legal instruments and national ethics and regulatory mechanisms in contemporary Hobbesian applications, raising concerns over their safety in cancer, $\mathrm{HIV}$, and schizophrenia risk estimates, for example. As critical concern issues, private personal medicine and associated lifestyle treatments as an outgrowth of colonial eugenics are not accessible to many impoverished indigenous and ethnic groups who suffer disproportionally from high rates of disease. Nor do they address social determinants of health underlying common diseases. In addition, the psychological harm of predicting unproven genetic vulnerability in psychotic illnesses that are highly stigmatizing among trauma exposed populations is unknown and requires research.

Contradicting abstract nation building projects that reduce Sami national and Scandinavian women's identity to a genetic code, the Sami diaspora in North America is diverse. The people identify with multiple identities due to a long history of social interaction. Indicating that biology and culture are not static, bioanthropologists in their quest to discover the racial origins of Europeans uncovered Sami ancient mtDNA U5a1 at three Sami burial sites in the Kola Peninsula in northwest Russia, whereas U5b1 was absent. [38] Still, loaded with colonial valuations the research reinforces social biases the Sami are homogenous in support of commercial medical research on healthy individuals that utilize haplogrouping and haplotyping to assess disease risk. Common DNA variants assumed to be distributed in clusters in populations are marketed as the cause of schizophrenia by $23 \&$ Me despite evidence to the contrary. [39] This could lead to genetic labelling and re-stigmatize the Sami as a group together with Laestadians and Scandinavians in evaluations of U5 biospecimens as seen after the Kautokeino uprising, where Sami society was branded as genetically predisposed to psychosis.

In addition, mtDNA testing on Sami genetic proxies in North America problematizes identity for women in Scandinavia who may not harbour the modern Sami characteristics-or DNA assigned by geneticists with upgraded technology. This is a major concern, since Sami culture was supressed by restructuring female (and male) social roles combined with banning drum symbols, dress, songs, and celebrations that embodied historical knowledge that imparted meaning to the people's lives. In Scandinavia and North America, Sami and Sami descendants are working to repossess their heritage as seen in a proliferation of literature, films, art, state sponsored cultural ambassadors, etc., under the weight of exploitation of their bodies as a natural resource and re-commodification of Sami identity. 


\section{Transition to Post-genomic Science}

Challenging genetic models that negate cultural and social dimensions of human personality and cognition, new research establishes that the environment plays a defining role in several multifactorial diseases. [40] In emerging studies on inflammatory schizophrenia, HLA influenced by demographic factors is thought to determine risk in geographical populations, while the environment initiates disease and regulates its progression through a multi-step process beginning in utero. It is now accepted that the human genome is made up of at least 50 percent of viruses that recombine and influence immune genes through interaction with hormones and environmental co-viruses (e.g. influenza A) in major psychoses. [41]

Human endogenous retroviruses (HERVs) make up approximately 8 percent of the genome and HERV-W viral genes involved in both placenta and brain development evolve critically through interactions in a fetus during the perinatal period, and subsequently, over an individual's life. In a holistic understanding of schizophrenia, co-infections and malnutrition are suggested to act together to cause preeclampsia and produce schizophrenia phenotypes by triggering activation of HERV elements, which can affect an embryos DNA structure through HERV-W coded enzymes. This creates uncontrolled modification of copies in embryonic cells that are capable of responding to triggering events that cause inflammation and glial death in the brain later in life. Unequal environmental stress loads, in fact, may be behind genomic structural changes and chronic illness among indigenous groups with high rates of psychosis today. Presently, it is reasonable to assume that schizophrenia may not be inherited as propounded by geneticists, but rather generated by the environment in each generation. [36]

The finding warrants additional research in view of failed attempts by population geneticists to identify causative genes for schizophrenia. It is introduced here to disclose a shift from eugenic to scientific explanations for serious psychiatric disorders based on the discovery of mobile genetic elements. HERV viral genetic research challenges the validity of genomics as a framework for human cognition, and more generally, a scientific discipline.

\section{Conclusion}

Historically, intellectuals endorsing modern values perceived Scandinavian Sami as a homogenous population on the basis of shared culture and used them as genetic laboratories. In the nineteenth century, the Swedish missionary Lars Levi Laestadius pathologized Sami women by applying French passion theory to explain religious ecstasy common to both shamanism and revival movements during the period. Afterwards, Sami women and men were stigmatized in eugenic studies on Sami psychopathology. Moreover, their national identification as mentally inferior discriminatorily made it easier for the Sami women to be exposed to sterilization policies in Sweden and Norway. The finding is in need of further research led by Sami scholars in light of international indigenous rights and conventions. 
In an intersectional critique of colonization in Sapmi, mutually reinforcing state policies and actions can be observed promoting assimilation and loss of status among Sami, particularly women, in Sweden. As a result of transatlantic immigration processes, integration into new communities, and suppression of identity by first generation Sami relative's cultural memory was also supressed in the North American diaspora. This led to newgenic commercial opportunities to exploit female Sami DNA by American consumer genetic companies who market mtDNA testing to Scandinavians. Representing potential new forms of manipulation of indigenous biology, 23\&Me has expanded their genetic health operation in Canada to avoid FDA regulations on health testing. The globalization of personal medical research circumvents rights, ethics, and quality control standards that promote health safety and equality from the standpoint of Canadian Aboriginal women who have high rates of poverty and disease in the country linked to European colonialism.

Currently, Sami, Laestadian, and Scandinavian women are universally at risk of being socially maligned in personal DNA research on psychotic disorders. Sami North Americans coded by Sami mtDNA U5b1 have no political identity, therefore, commercial genomic firms are under no obligation to observe international or national indigenous legal instruments as a modernization in post-colonial genomics. To conclude, this article has attempted to illustrate that biological and cultural genocide co-exist in Swedish colonial history and that race based on national identity is central to eugenics. Moreover, that gendered applications evolved innovatively in colonial medicine and eugenics, and now demand new culturally informed scientific approaches in psychiatry.

\section{References}

1. Pentikainen J (ed.) Fragments of a Lappish Mythology. Ontario: Aphasia Books; 2005.

2. Jensen EM (ed.) What We Believe In: Sami Religious Experience and Beliefs from 1593 to Present. Norway: CálliidLágádus/Authors Publishers; 2015.

3. Svalastog AL. The sami are just like everyone else? A scientist of religion looks at the encounter between the christian missionary religion and the Sami ethnic religion. In: Tunon RH, Franden M, Ojal CG, Ohman MB (eds.) Uppsala mitt i Sápmi, Report from Symposium by Föreningen för samiskrelaterad forskning i Uppsala, Upplandsmuseet 4-5 May 2011. CMB's skrifserie 55; 2011. 22-27.

4. Helender E, Kailo K (eds.) No beginning, No End: The Sami Speak Up. Canada: Circumpolar Institute; 1998.

5. Gunlög F. Colonialism in the Margins: Cultural Encounters in New Sweden and Lapland. Leiden: Brill; 2006.

6. Kuokkanen R. Sami women, autonomy, and decolonization in the age of globalization. Rethinking Nordic Colonialism. Act 4: Finnish Sapmi [Internet]. 2006 June [cited 2015 July 20]; 1-18. Available from: http:// https://rauna.wordpress.com/

7. Turda M. Modernism and Eugenics. England: Palgrave Macmillan; 2010.

8. Turda M. Race, science, and eugenics in the twentieth century. In: Bashford A and Levine $\mathrm{P}$ (eds.) The oxford handbook of the history of eugenics. Oxford: Oxford University Press; 2010. 62-79. 
9. Give Us Our Skeletons. Directed by: Paul Anders Simma. Icarus Films. [Internet]. New York: 2000. Available from: http://icarusfilms.com/new2000/giv.html

10. Moses DA. Conceptual blockages and definitional dilemmas in the 'racial century': genocides of indigenous peoples and the holocaust. In: Moses DA (ed.) Colonialism and genocide. Abingdon: Routlage; 2007. 169-174.

11. Mikkelson JM (ed.) Kant and the Concept of Race: Late Eighteenth Century Writings. New York: SUNY Press; 2013.

12. Hallencreutz, CF. Laestadius' attitude to Sami religion. Scripta Instituti Donneriain Aboensis 2014 ; 12: 170-184.

13. Laestadius L. Darhushjonet. Sections 3-4 [Internet] Laestadiustexter.se; No date [cited 2015 July 20]. Available from: http://www.laestadiustexter.se

14. Kvist R. Nomadic Saami and alcohol: Jokkmokk parish, 1760-1910. Can J Native Stud 1992; 12 (2): 185-201.

15. Laestadius L. Crapula mundi [Internet] Laestadistexter.se; 1843 [cited 2015 July 20]. Available from: http://laestadiustexter.se

16. MacPherson CB (ed.) Leviathan. England: Penguin Books; [1951] 1968.

17. MacPherson CB (ed.) The Political Theory of Possessive Individualism. Oxford: Oxford University Press; 1962.

18. Pietikainen P. Neurosis and Modernity: the Age of Nervousness in Sweden. Leiden: Brill; 2007.

19. Heniz A. Colonial perspectives in the construction of the psychotic patient. Sage. 1998; 18 (4): 421-422.

20. Novella EJ. La medicna de las pasiones en la España del siglo XIX. Dynamis 2011; 31(2): 453-473.

21. Friedland R. 'Money, sex, god: the erotic language of religious nationalism. Sociol Theor. 2002;20(3):381-425.

22. Broberg, G, Roll-Hansen N (eds.) Eugenics and the Welfare State: Norway, Sweden, Denmark, and Finland. Michigan: Michigan University Press; 2005.

23. Hirvonen V. Voices from Sapmi: Sami Women's Path to Authorship. Trans Anttonen, K. Norway: DAT; 2008.

24. Lindqvist J. Reindeer herding: a traditional indigenous livelihood. Maquiarie J Int'l \& Comp Entl L 2009; 6: 83.

25. Kivst R. The racist legacy in modern Swedish Saami policy. Can J Native Stud 1994; 14 (2): 203-220.

26. Kvist R. Swedish Sami policy, 1550-1990. In: Kivist R (ed.) readings in Sami history, culture and language III. Umea: Centre for Arctic Cultural Research; 1992.

27. Lehtola VP. The Sami People: Traditions in Transition. Trans Muller-Wille LB Fairbanks: University of Alaska Press; 2004.

28. Hepokoski, W. Lars Levi Laestadius and the revival in Lapland [Internet]. 2002 [cited 2015 July 20]; 1-53. Available from: http://users.erols.com/ewheaton/lars/lars.pdf

29. Stewart M. Give us or skeletons. Vis Anthropol Rev. 2000-2001; 16: (2): 97-98.

30. Laestadius, L. The Voice of One Crying in The Wilderness. Trans The Old Apostolic Lutheran Church of America; [1852-54] 1988.

31. Andresen A. In the wake of the Kautokeino event: changing perceptions of insanity and the Sami 152-1965. Acta Borealia 2007; 24 (2): 130-142. 
32. Möjen JA. Harmonic and unharmonic crossings (racetypes and racecrossings in northern norway). Eugen Rev 1922; 14: 35-40.

33. Silversparf A. Sami genealogy research as resistance and practice: countering ethnical cleansing and reclaiming our memory, history and culture. In: Gärdebo J, Öhman, MB, Maruyama H (eds.) Re: Mindings constituting indigenous/academic/artistic knowledges. Uppsala: Uppsala University; 2014. 131-142.

34. Axelsson P, Skold P. Indigenous populations and vulnerability: characterizing vulnerability in a Sami context. Ann Demogr Hist 2006; 1 (3): 115-132.

35. Svalastog AL. Making it transparent. On naming, framing and administering biobank research on native people. New Genet Soc 2013; 32(3): 209-242.

36. Jensen EM. We Stopped Forgetting: Stories by Sami Americans. Norway: CálliidLágádusAuthor's Publisher; 2012.

37. Marttinen, T. Decolonizing genes, identities, and bodies of Canadian indigenous and immigrant Sami women. Master's thesis. Oxford Brookes University; 2014. 1-94.

38. Sarkissian CD, Balanovsky O, Brandt G, Buzhilova A, Koshel S, Zaporozhchenko V, Gronenborn $\mathrm{D}$ et al. Ancient dna reveals pre-historic gene flow from Siberia in the complex human population history of north east Europe. PLOS Genet 2013; 9 (2):1-17.

39. Erin C. $23 \& \mathrm{Me}$ Blog. SNP watch: researchers show importance of common disease variants in schizophrenia [Internet]. 2009 [cited 2015 August 22]; Available from. http:// blog.23andme.com/23andme-research/snpwatch/snpwatch-researchers-show-importance-of-common-dna-variants-in-schizophrenia/

40. Nath, A. Küry P. Sciscia do Olival G, Dolei A, Karlsson H, Groc L, et al. First international workshop on human endogenous retroviruses and diseases, herv \& disease. Mob DNA. In press 2015.

41. Perron H, Hamdani N, Faucard, R Lajnef M, Jamain S, Daban-Huard C et al. Molecular characteristics of human endogenous retrovirus type- $\mathrm{w}$ in schizophrenia and bipolar disorder. Transl Psychiatry 2012; 2: 1-10. DOI: 10.1038/tp.2012.125

\section{Bibliography}

Alzu'bi A, Leming L,Watzlaf, V. Personal genomic information management and personalized medicine: challenges, current solutions, and roles of HIM professionals. Perspective in Health Management [Internet]. No date; Available from: http://perspectives.ahima. org/personal-genomic-information-management-and-personalized-medicine-challenges-current-solutions-and-roles-of-him-professionals/\#.VeNYEPIViko

Benjamin, R. A lab of their own: genomic sovereignty as postcolonial science policy. Policy and Society 2009; 28: 341-355.

Böök JA. A genetic and neuropsychiatric investigation of a north-Swedish population: with special regard to schizophrenia and metal deficiency. Acta Genet Stat Med 1953; 4 (1): $1-100$.

Bourassa C, McKay-Mcnabb K, Hampton M. Racism, sexism, and colonialism: the impact on the health of aboriginal women in Canada. Can Woman Stud 2004; 24: 23-30.

Bunnik EM, Schermer, Cecile A, Janssens JW. The role of disease characteristics in the ethical debate on personal genome testing. BMC Med Genomics 2012; 5 (4): 1-9.

Campbell I, Gambin T et al. Human endogenous retroviral elements promote genomic instability via non-alleic homologous recombination. BMC Biol 2014; 12: 1-10. 
Carlson L. Fjeld, F. Nakai. Finding the home within us: intergenerational trauma and healing among North American Sami. Baiki 2007; (28): 6-8, 18.

Feschotte C, Gilbert C. Endogenous viruses: insights into viral evolution and impact on host biology. Nat Rev Genet 2012; 13:

Gershon ES, Alliey-Rodiquez N. New ethical issues for genetic counselling in common mental disorders. Am J Psychiatry 2013; 170 (9): 968-978.

Hart EJ. Reindeer Days Remembered. Inuvik: Inuvialuit Cultural Resource Centre; 2001.

Holmio A. History of the Finns in Michigan. Trans E. Ryynanen. Michigan: Wayne State University Press; 2001.

Hudson G, Gomez D, Wilson IJ. Chinnery PF. Recent mitochondrial dna mutations increase the risk of developing common late onset human diseases. PLOS Genet 2014; 10 (5): DOI: 10.1371/journal.pgen.1004369.

Jastad HL. Viewing ethnicity from the perspective of individuals and households: Finnmark during the late nineteenth century. In: Axelsson P, Skold P (eds.) Indigenous peoples and demography: the complex relation between identity and statistics. New York: Berghahn; 2011. 149-162.

Kennet D. DNA and Social Networking: a Guide to Genealogy in the Twenty-first Century. United Kingdom: The History Press; 2011.

Kera D. Bionetworking over dna and biosocial interfaces: connecting policy and design. Genomics, Society, and Policy 2010; 6: 47-60.

Kyllingstad JR. Measuring the Master Race: Physical Anthropology in Norway, 1890-1945. Cambridge: Open Book Publishers; 2014.

Leboyer M, Tamouza R, Charron D, Faucard R, Perron H. Human endogenous retrovirus type $\mathrm{w}($ herv-w) in schizophrenia: a new avenue of research at the gene-environment interface. The World J Biol Psychiatry 2011; 0: 1-11.

Hammer, O. Old new religions in Scandinavia. In: Lewis Jr, Tollefsen IB (eds.) Handbook of Nordic new religions. Netherlands: Brill; 2015. 36-61.

Marchbanks RM, Ryan M, Day IN, Owen M, McGuffin P, Whatley SA. A mitochondrial dna sequence variant associated with schizophrenia and oxidative stress. Schizophrenia Res 2003; 65: 512-517.

Marttinen, T. Herv-w ecology of psychosis: a new prescription for health, equality, and citizenship in a post-genomic world. Honour's thesis. Algoma University; 2012. 1-70. DOI: 10.14130/RG.2.1.3909.7441

Mattson G. Nation state science: Sweden's ethnoracial purity. Comp Stud Soc and Hist. 2014; 56 (2): 320-350.

Minde H. Constructing 'Laestadianism': a case for Sami survival?. Acta Boreal 1998; 15 (1): 5-25.

Rogers J, Nelson, M. "Lapps, Finns, Gypsies, Jews, and idiots" modernity and the use of statistical categories in Sweden," Ann Demogr Hist 2003; 1 (105): 61-79.

Roy CK. Indigenous women a gender perspective [Internet]. Norway: Resource Centre for the Rights of Indigenous Peoples; 2004 May [cited 2015 July 20]; Available from: http:// www.galdu.org/govat/doc/indigenous_women_croy.pdf

Sonden, CV. Memoir on an epidemic religious ecstasy which prevailed in Sweden in 1841 and 1842. Dublin J M 1843; 24 (2): 226-237.

Tallbear K. Native American DNA: Tribal Belonging and the False Promise of Genetic Science. Minneapolis: University of Minnesota Press; 2013. 
United Nations Interagency Support Group. The health of indigenous peoples [Internet]. 2014 [cited 2015 August 26]; Available from: http://www.un.org/en/ga/president/68/pdf/ wcip/IASG\%20Thematic\%20Paper\%20-\%20Health\%20-\%20rev1.pdf

Valkonen S, Wallenius-Korkalo S. Embodying religious control. intersectional approach to Sami women in Laestadianism. Culture and Religion 2015; 16 (1): 1-16.

Vorren, O. Saami Reindeer and Gold in Alaska: the Emigration of Saami from Norway to Alaska. Illinois: Waveland Press; 1994.

Wagner-Harkonen J. Honouring our Sami ancestors. Arran (54 \&55): 2009-2010; 1-19.

Whitehouse H, Martin LH. Theorizing Religions Past: Archeology, History, and Cognition. California: Altamira Press; 2004.

\section{Websites}

CTV News. U.S company now offering genetic health, ancestry info for Canadians [Internet]. 2014 [cited 2015 August 22]; Available from: http://www.ctvnews.ca/health/u-s-company-now-offering-genetic-health-ancestry-info-for-canadians-1.2033046

Eira, BM. DNA-iskosiiguin eat allge gal goassege [Internet]. 2015 [cited 2015 August 22]; Available from: http://avvir.no/2015/03/dna-iskosiiguin-eat-algge-gal-goassege

Moore, CC. Genetic genealogy news from finnfest [Internet]. 2011 [cited 2015 August 22]; Available from: http://www.yourgeneticgenealogist.com/2011/08/genetic-genealogynews-from-finnfest.html

Veen, AH. Nordic genealogy conference. [Internet]. 2013 [cited 2015 August 22]; Available from: http://www.prairierootsresearch.com/nordic-genealogy-conference/

Submitted: 8. 9. 2015.

Reviewed: 20. 10. 2015.

Accepted: 11. 11. 2015. 